\section{Det eventyrlige}

\section{Plejebørn og adopterede \\ i dansk litteratur}

af lektor Allan Roder

I

en nu næsten glemt novelle fra 1830'erne af Thomasine Gyllembourg fortælles om et københavnsk plejebarn. I indledningen bliver der sat spørgsmålstegn ved, om alt eventyrligt nu også er "reent forsvundet af Virkeligheden", og herefter følger historien om Nisida. ${ }^{1}$ Fra hun er helt lille, vokser hun op som datteren i et godt og trygt hjem. Ingen $i$ hendes nye familie ved noget om hendes biologiske forældre i udlandet; først da hun er voksen, kommer der oplysninger frem om dem og om hendes historie og baggrund.

Men ud over disse træk er der i beretningen tilføjet en del mere eventyrlige. Fx at hun på dramatisk vis overdrages til plejefamilien af en mystisk person i en karet, at hun har en farverig og meget usædvanlig adelig familie i udlandet, at hendes danske plejebror drager ud i verden og ved et rent tilfælde får til opgave at arbejde for en venlig greve, der viser sig at være svoger til Nisidas biologiske mor.

I dansk litteratur findes en del beretninger om børn, som mister deres oprindelige forældre meget tidligt og kommer over i en ny familie med nye forældre, ny identitet og uden viden om historie og baggrund. De går langt tilbage og kan findes inden for alle litterære genrer. Man finder dem blandt folkeeventyrene, hvor alting jo kan ske, og forældreløse børn ofte fører en meget omtumlet tilværelse, men også i andre historier.

Ikke mindst i romaner og noveller, hvor der kan være både drama og romantik, utrolige sammentræf og børn, der under mystiske eller usædvanlige omstændigheder er kommet bort fra deres biologiske ophav. Det eventyrlige er stadig meget tydeligt til stede.

Som læser får man som regel et indtryk af omstændighederne omkring barnets overgang til en anden og fremmed familie, og af den nye familie og barnets forhold der.

Og nogle gange fortsætter historien med at beskrive, hvordan det går nogle år senere, når børnene er blevet til unge mennesker, og forbindelsen mellem dem og deres oprindelige familie genetableres.

\section{Adskillelsen}

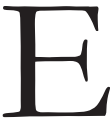

$\mathrm{t}$ af de mest afgørende øjeblikke i børnenes historie er, når de skilles fra deres biologiske familie for at blive optaget $i$ en anden. $\mathrm{Da}$ der i disse historier som oftest er betragtelige forskelle på forholdene i de to miljøer, står det klart, at skiftet fra den ene familie til den anden nemt kan få store konsekvenser for barnet og i nogle tilfælde kan vende fuldkommen op og ned på dets liv og fremtidsudsigter.

Når det drejer sig om eventyr, er der ofte tale om, at børn bliver røvet fra deres forældre, som når dronningens onde søstre bortfører hendes tre 


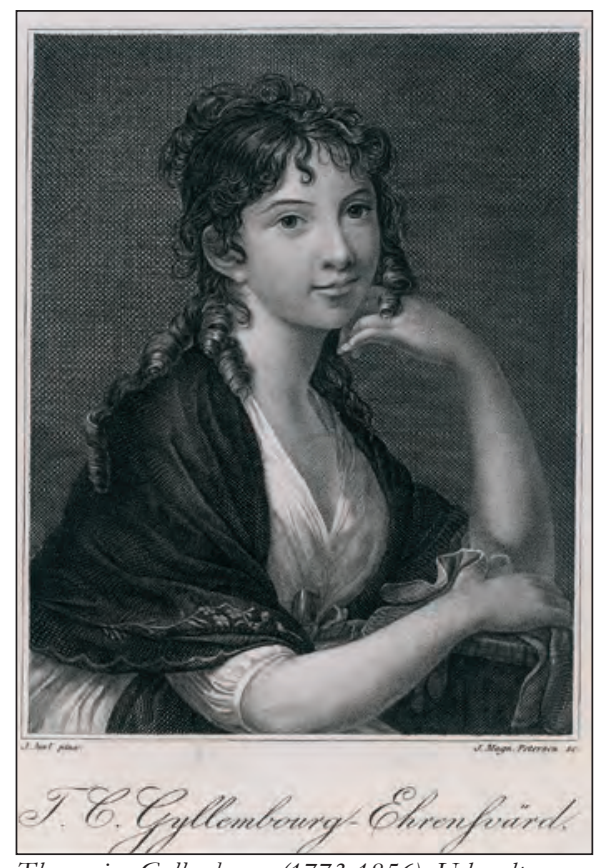

Thomasine Gyllembourg (1773-1856). Udsendte som 53-airig den forste af sine 24 anonymt udgivne store noveller; de skildrer kulturnormer, karakterer og samvarsformer i guldaldertidens kobenhavnske middelklassefamilier og bidrog derved til at frembringe en ny, popular realistisk roman.

børn, der bliver kastet $i$ vandet og driver med strømmen, til de bliver fundet og kommer til at vokse op hos et barnløst ægtepar langt fra hoffet. ${ }^{2}$

Hos mange af det 19. århundredes forfattere kan overgangen fà et næsten lige så eventyrligt skær, - som $i$ en scene hos Christian Winther: en bonde har fået et varsel, der om natten byder ham at gå til Troldestuens hule eg og ellestubben; da han når derud, ser han en forførende, fornemt klædt ung kvinde med overtoner af naturvæsen, som grædende peger på en kurv og flygter. I kurven ligger et spædbarn med fine klæder og en seddel, der fortæller, at netop han må tage sig af den lille Helene. ${ }^{3}$

Voldsommere går det til i St. St. Blichers historie om Marie og H.C. Andersens "En Historie fra Klitterne" om Jørgen; i begge historier er der tale om dramatiske skibsforlis ved den jyske vestkyst, hvor veletablerede forældre omkommer efter at have kæmpet sig vej gennem brændingen med deres børn, som lokale fiskere derefter tager til sig som deres egne. ${ }^{4}$

Også i Nisidas tilfælde er der dramatiske træk inde i billedet og gode grunde til, at hun ikke kunne blive i sin biologiske familie. Hendes forældre (en fornem spansk frøken og en fransk baron) har været gennem store trængsler, og der er gået et hemmeligt forhold og nogle voldsomme hændelser forud:

"Natten efter Fødslen døde pludselig den af Sorg og Ængstelse afkræftede Moder. Baronen, der bestandig speidede omkring hendes Bolig, erfarede allerede tidlig om Morgenen sin Ulykke og blev saa angreben deraf, at han neppe kunde naae sit Logis, før en hidsig Feber anfaldt ham og berøvede ham al Samling." 5

\section{Situationen er kaotisk, og} alle er forståeligt nok noget fortumlede. afleveret til en forbipasserende, og da det fornemme køretøj er forsvundet om hjørnet, kan Nisidas borgerlige, københavnske tilværelse begynde.

I de allerfleste historier, både ældre og nyere, skal der meget til, før unge mødre må skilles fra deres børn, så når det alligevel sker, er omstændighederne ofte meget alvorlige. En ung 
9) reent forjumbet of Birfefigheben, at intet Memeifes Sib langere ipiller $t$ brogeoce zarver, men at bet henglis

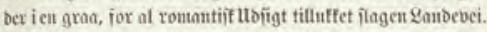
Sovor Mieget ber ent i vore Iiber tafer for Deme Meening,

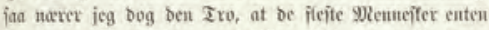

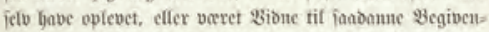
Feoer, ber, fyois be blebe inbjorte i ent bigtet fortulling, vilbe uwbe ben ofte gientague sebreibelje, at oc bare ujanbigntige. Mangen jant Tilbragelie af beme Beftaj= jenfec bliber af on elfer anten srumb iffe afminbelig befjentbt, eller, naar ben bliver bet, vaffer ben ingen fours unbring, efterjom bett fun befreiter ben gante Sectning, -at bet Sanbe iffe altio er fambinutigt."

Ẽn Begiventheo, jout jeg pel tor benfore tit ocmue Stasjic, er iffe bfot modt mig i nuir Utrgbour, men har $i$ fute zolger jaalebes gaact igjeutem mit Sib og havt

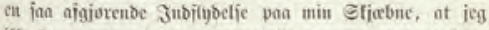
iffe fon nagte mig ben fornoiefie at optegue bens Dutifectbigheber, for jaatedes enbuu engatg at mybe bem i

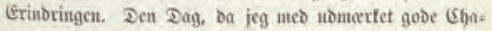
racterer fou bjeut fra Examen artiun, bar bet uetoy

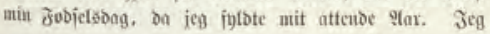
12*

Forste side af Thomasine Gyllembourgs historie Nisida'. Fra Samlede Skrifter 7, 1884 (Det Kongelige Bibliotek).

døende mor overgiver sit barn og en passende sum penge til en vaskekone $i$ håbet om, at der senere vil blive fundet en løsning. ${ }^{6}$ En anden valgte at gennemføre sit svangerskab vel vidende, at det ville koste hende livet, men var til det sidste "lykkelig for, at hun havde nået at give livets gave videre til et nyt slægtled"'?

Når mødre i mindre dramatiske situationer vælger at give deres barn bort, er situationen ofte den, at de har været usædvanligt unge, eller at de har været under hårdt pres og $\mathrm{i}$ realiteten ikke havde noget valg. Som når en diplomatfrue fra Holte forklarer sin datter, der er vokset op som adoptivbarn blandt vendsysselske fiskere: 'I begyndelsen afviste jeg tanken straks, men far og mor bearbejdede mig hårdt". ${ }^{8}$

\section{Den nye tilværelse}

$\mathrm{I}$ eventyrets verden kan barnets velkomst i den nye familie falde noget forskelligt ud. Det kan være velkomment hos barnløse, men kan også blive modtaget med skepsis og mistanke om, at barnet formentligt er født uden for ægteskab.

\section{Helene, Jørgen og Nisida} bliver alle stort set vel modtaget, selvom Jørgens nye mor en kort overgang bliver noget betænkelig ved hans sydlandske udseende, og det i Helenes tilfælde måske også kan spille ind, at der med barnet følger et tilsagn om tredive dukater årligt. En af årsagerne til, at de fremmede børn er velkomne, er, at man $i$ alle tre hjem for nylig har mistet et biologisk barn og endnu ikke er kommet over sorgen. Som Helenes plejefar udtrykker det -

"Jeg elsker hende næsten som mit eget Kjød og Blod,

Især fordi mit første Barn saa tidligt mig forlod"10

Hun får ikke de store tilpasningsproblemer. Hendes navn bliver i de nye omgivelser hurtigt til Lene, og hun ender med at styrke sit tilhørsforhold i plejeforældrenes miljø ved som byens rigeste og smukkeste brud at gifte sig med sønnen fra nabogården og tegner til at ville gå en lys fremtid i møde i det lille samfund.

$$
\text { Langt værre går det med }
$$
Marie. Hun bliver modtaget med visse forventninger og bliver opkaldt efter 
den biologiske datter, som hendes plejeforældre tidligere har mistet, men falder aldrig helt til. Som voksen kommer hun til at føle sig som "en Fremmed og en Udlænding", ${ }^{11}$ forelsker sig, men mister sin tilkommende og bliver herefter sindssyg.

Nisida har arvet et iltert, sydlandsk temperament, og også Jørgen kan få problemer, når der var "Noget i hans høiadelige spanske Blod, der kogte op", ${ }^{12}$ men begge er de derudover usædvanligt begavede børn med evner og kreative talenter. I Jørgens miljø hos den fattige vestjyske fiskerfamilie er der dog ikke mange muligheder for at udvikle og få gavn af de medfødte evner. Han er opvakt, musikalsk, kunstnerisk og har store evner, men har i de første mange år ingen forbindelse med nogen, der eventuelt kunne hjælpe ham på vej, havner uforskyldt i fængsel og er meget tæt på at gå til grunde.

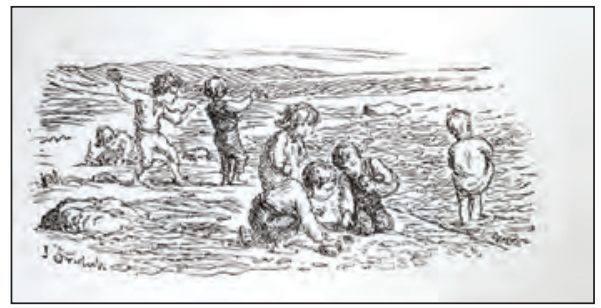

"Der vare mange Strange spandte i det Bryst, de kunde bave klinget ud $i$ Verden, var han bleven stillet andetsteds, end i Fiskerbuset ved Vesterbavet". En Historie fra Klitterne of H.C. Andersen. Tegning af Lorenz Frolich.

Nisida derimod kommer som lille ind i en forholdsvis velsitueret familie i København og får i de trygge, borgerlige omgivelser gode vækstbetingelser. Her lærer hun hurtigt, men bliver aldrig helt igennem dansk; hun beholder sit oprindelige navn og overvejer endda på et tidspunkt stærkt at gå over til katolicismen. Men på trods af, at stærke udenlandske kræfter bejler til hende, ender hun med at holde fast ved den danske kultur, hun er vokset op med, og den lutherske lære. Denne beslutning er stærkt motiveret af hendes plejemor. Nisida er et nemt og kærligt barn, der sætter pris på, hvad moren gør for hende og ender med at leve op til sine ord til sin mor: "jeg vil troe som du og leve som du; intet Menneske kan være frommere og bedre, end du er". ${ }^{13}$ Senere får Nisida sin belønning for sin trofasthed, da det hele ordner sig for hende.

\section{At slå rod}

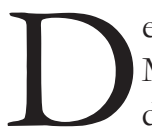
er bliver $\mathrm{i}$ fortællingerne om Marie og Jørgen spurgt, om de små sydlændinge mon vil kunne klare sig i det barskere klima, som de er blevet omplantet til, eller om de vil visne i sandet. ${ }^{14} \mathrm{Og}$ det kan vel også siges, at $\mathrm{i}$ ingen af de to historier ender de med at blive helt almindelige som alle andre. De har i sig noget, der ikke altid passer med de danske forventninger.

Hvor Helene og Nisida ender med at blive grundfæstet som en selvfølgelig del af inderkredsen i deres nye omgivelser, går det anderledes med Marie og Jørgen. Det bryllup med en indfødt dansker, der ville have forankret dem i en naturlig og selvfølgelig position blandt de lokale, kommer meget tæt på at blive en realitet. Men i forbindelse med at de mister deres tilkomne, følger der en form for mentalt sammenbrud, og de ender med i en vis forstand at stå udenfor i det lille samfund. 
Spørgsmålet om, hvordan

rødderne klarer omstillingen, beskæftiger også Karen Blixen i "Alkmene" og "Det drømmende Barn". De børn, som der fortælles om i de to vintereventyr, har begge mistet deres egne forældre og fået nye familier og en ny mor, som de får et problematisk forhold til; i Alkmenes tilfælde, fordi hun ikke forstår sit nye barn og dets behov, og i Jens', fordi hun ikke kan få sig selv til at holde af ham. Begge børnene er talentfulde og begavede, men trives ikke i deres nye miljø, og deres evner går til spilde.

Alkmene stammer fra et kunstnerisk miljø i København. I den afsides, forfaldne jyske præstegård, hendes nye hjem, bliver Mene udsat for en moralsk, religiøs påvirkning, der stemmer dårligt med hendes naturlige tilbøjeligheder og hæmmer hende voldsomt. Hun beskrives som et usædvanligt kunstnerisk og kreativt barn med aristokratiske tendenser, men får i sit nye miljø i præstegården ikke de vækstbetingelser, som hun har brug for. Hendes biologiske mor var efter al sandsynlighed ved balletten, men da det viser sig, at Alkmene også selv har evner for at blive danserinde, støder hun på massiv modstand hos sine plejeforældre, og hendes medfødte evner kommer aldrig til udfoldelse.

Jens er en dreng fra fattigkvarteret, som et velhavende ægtepar har taget til sig for at få en arving til et hæderkronet familiefirma, men efter at have hørt historier og eventyr om de rige og om, hvordan deres børn på gådefuld vis nogle gange kan forsvinde, fylder han sin tilværelse med drømme og fantasier om sin biologiske familie. Han bruger sit medfødte kreative talent til at fabulere og drømme, men forsømmer at slå rod - som et ungt træ, forklares det, der ved en omplantning har fået bøjet sin pælerod og nu prøver at klare sig ved $i$ stedet at danne en mængde små, fine rødder nær ved overfladen. ${ }^{15}$ Men den slags rødder er ikke nok til at overleve med i længden.

\section{Hos de nye forældre}

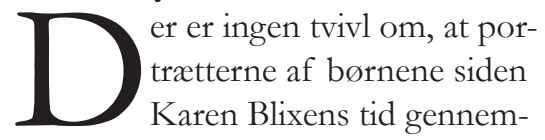
gående har ændret sig en del, og der er blevet længere imellem de kunstneriske, højt begavede børn med den fine og nogle gange aristokratiske biologiske familie. Og tilsvarende er der generelt kommet en mere realistisk, hverdagsagtig tone ind end tidligere, når det drejer sig om beskrivelsen af tilværelsen hos de nye forældre.

Uoverensstemmelser og hverdagsskænderier i den familie, som barnet bliver optaget i, skildres ikke så ofte i de ældre historier, men er et hyppigt element i de nyere. Der kan blive kriser, når barnet først i en temmelig sen alder får noget at vide om det manglende biologiske slægtskab. Nogle reagerer med bebrejdelser og hurtige beslutninger: "I har løjet for mig altid. Jeg vil finde mine forældre i Marokko". ${ }^{16}$ I andre tilfælde kan den uventede oplysning medføre en pludselig teenagetrang til at prøve grænser af og opføre sig på en måde, der nødvendigvis må stille de nye forældre på en hård prøve, og der eksperimenteres med stoffer, natlige gæster, sikkerhedsnåle i kinden, voldsomme 
tatoveringer og grønt strithår. ${ }^{17}$

I den moderne adoptivfamilie bliver børn og forældre nemt involveret $i$ forbitrede opgør omkring det tidspunkt, hvor søgningen efter den biologiske familie begynder. ${ }^{18}$ I overgangsfasen, hvor der gøres op med de hidtidige rammer, og de første skridt skal gøres for at finde frem til de nye, bliver der sagt mange sårende og ubehagelige sandheder.

Nogle gange kan vedvarende tavshed dog være endnu værre. I et af Astrid Saalbachs TV-spil har den adopterede Myung svært ved at tilpasse sig forholdene i sit nye hjem og nægter at sige noget. Hendes opførsel er så anstrengende, at det er ved at få hele familien til at falde fra hinanden. ${ }^{19}$

I Kirsten Thorups roman Elskede ukendte genkender man forst noget,

KIRSTEN THORUP
ELSKEDE UKENDTE
om gammelkendte
handlingsmøn-
stre: et meget
velhavende par
adopterer en fattig
dreng for at få en
arving til familie-
firmaet og ændrer
hans navn - fra
Ronnie til Karl
,- så det passer

bedre med de nye omgivelser. Ligesom i flere af de ældre historier understreges også her den biologiske arvs betydning, og der stilles skarpt på en situation, hvor et barns medfødte evner og egenskaber ikke stemmer overens med det miljø, som det er havnet i - blot med den forskel, at det i Karls tilfælde er barnet, ikke miljøet, der ikke kan leve op til, hvad man kunne have forventet. Det fremmede barn har i dette tilfælde ingen kunstneriske evner og kan ikke overraske sine nye forældre med nogen overlegen begavelse. Der er langtfra noget aristokratisk over ham, og da han bliver voksen, åbenbarer han ingen skjulte talenter, men viser sig som neurotisk, sadistisk og brutal.

Hans adoptivforældre er beskrevet som mennesker af en helt anden og finere støbning, og det står de langtfra alene med: selvom portrætter af adoptivforældre kan være meget forskellige, er der en klar tendens til, at de $i$ vore dage skildres som mere kreative, begavede og indfølende end tidligere, og de gør sig flere anstrengelser for at forstå den fremmede, der er kommet ind i deres familie, end det var almindeligt før i tiden. Nogle gange fremstilles de nye mødre som talentfulde kunstnere med en større indfølingsevne, end godt er, så de automatisk føler sig som den egentlige skyldige i forbindelse med enhver uoverensstemmelse, uanset hvor uforskyldt de er kommet ind i situationen. ${ }^{20}$

Men mens der i de færreste historier stilles spørgsmålstegn ved de unge biologiske mødres følelser for deres lille barn, stiller sagen sig anderledes, når det drejer sig om de nye mødre, som senere optager det i deres familie. I mange tilfælde optræder der stadig, også i vore dages skildringer, en vis skepsis med hensyn til de nye forældres egentlige følelser over for barnet og deres motiver, som snarere end forældrekærlighed fx kan være ønsket om at gøre en medmenneskelig gerning for et forældreløst 
barn, eller at finde en arving til ejendomme og besiddelser. I nogle tilfælde har barnet fra begyndelsen af fàet en blandet modtagelse, fordi det egentlig kun var manden, der ønskede adoptionen, og konen oprindelig var imod ('Hun gik med til adoption, hvis hun til gengæld fik sit atelier"). ${ }^{21}$ Også hvis situationen er den, - som den ofte er blevet beskrevet, lige fra folkeeventyrenes tid til vore dage, - at parret egentlig ønsker en erstatning for deres eget biologiske barn, som er død nogen tid i forvejen, kan det få en vis betydning, og barnet kan ende med at få en lidt mere stedmoderlig behandling. At finde tilbage tilværelsen, men ikke noget mål i sig selv at finde tilbage til rødderne. Et eksempel er eventyret "Rige Per Møller", hvor drengen kommer fra sine fattige biologiske forældre til Per Møller og siden bliver opfostret hos plejeforældre. Da han er stor nok, rejser han helt til Helvede og risikerer liv og lemmer for der at få svar på nogle spørgsmål, som han skal have opklaret for andre, og som kun Fanden selv kan svare på. Senere bliver han en rig greve og skal giftes med Per Møllers eneste datter. Men det falder ham aldrig ind at spørge om, hvem hans biologiske familie var.

\section{Anderledes stiller sagen sig} dog i brødrene Grimms version af eventyret om kongeparret, hvis tre børn røves og opfostres hos en fisker og hans kone. En af sønnerne drager en dag ud i verden for at genfinde sin biologiske far. Det lykkes ikke, men længere henne i hi-

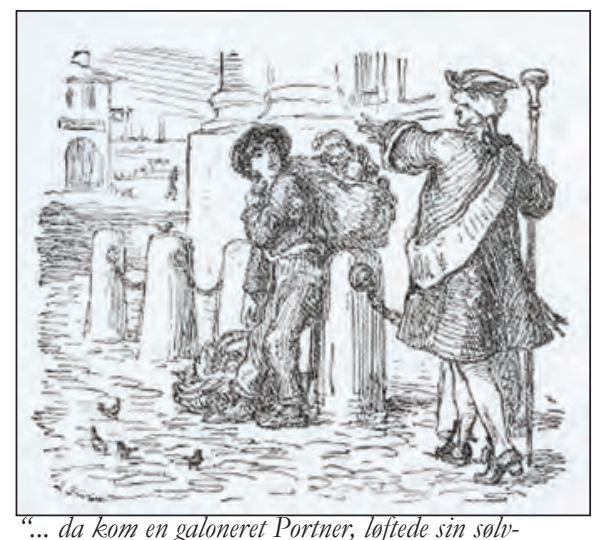

"... da kom en galoneret Portner, loftede sin solv beslagne Stok imod ham og jog ham bort, ham - Husets Barnebarn, men det vidste Ingen der; han allermindst." En Historie fra Klitterne af H.C. Andersen. Tegning af Lorenz Frolich.

storien mager tilfældet, at kongen af sig selv en dag falder indenfor i børnenes nye hjem, hvor en talende fugl sidder parat til at forklare, hvordan tingene hænger sammen. ${ }^{22}$

Sådanne historier, hvor børn og unge af forsynet ledes i retning af deres biologiske forældre, er ikke så sjældne i det 19. århundrede. Også H.C. Andersens Jørgen, som ellers i sin vestjyske hverdag blandt fiskerne ikke gør sig nogen overvejelser om sin biologiske baggrund og i øvrigt slår sig til ro med den fromme tanke, at det alt sammen vil klare sig i livet efter døden, bliver som kahytsdreng af forsynet fort direkte hen foran det hus i Spanien, hvor hans bedstefar bor.

Fru Gyllembourgs Nisida synes heller aldrig at gøre sig nogen tanker om sin oprindelse. Lige så lidt som Jørgen stiller hun nogen spørgsmål og foretager sig intet for at finde frem til nogen viden om sin baggrund. Men tilfældet kommer hende til hjælp, og hun 
formår i sidste instans at få det bedst mulige ud af sin situation som medlem af to forskellige familier. Det lykkes hendes franske far at finde hende, da hun er blevet voksen, og han er begejstret for at møde hende, ikke mindst på grund af hendes forbløffende lighed med hendes afdøde biologiske mor. Der opbygges altså, bl.a. takket være den biologiske arv, hurtigt et solidt og godt forhold imellem far og datter, - samtidig med at hun er i stand til at fastholde sit nære og varme forhold til sin danske plejefamilie. Hun er forankret i det danske, samtidig med at hun interesserer sig for det sydeuropæiske. Og historien får en lykkelig slutning, hvor der er plads til begge kulturer.

Også for andre kan nedarvede egenskaber få betydning for, hvordan genforeningen kommer til at udforme sig. Blichers Vang har på mange måder været heldig med sin opvækst, og han er sin plejefar taknemmelig for at have taget sig af ham.

Alligevel har han det dårligt med sin situation, "en Frugt af forbuden Elskov, falden i Mørke fra Stammen, og i Mørke henslængt saa langt, at jeg neppe igjen skal finde den". ${ }^{23}$ Han går ud fra, at hans forældre kommer af middelklassen, men ved ellers intet. Han er besluttet på at undersøge sagen nærmere, men da mulighederne for undersøgelser er begrænsede, ender han med - i mangel af bedre - at gå til en spåkone. Denne fremgangsmåde viser sig imidlertid at give uventet hurtige resultater:

"Jeg besøgte hende, og spurgte: om hun kunde sige mig, hvo mine Forældre vare? - Længe saae hun paa mig, med sine stive dumme Fiskeøjne, og gav derpaa det Oracelsvar: det første Mandfolk, min Søn, som Du møder, naar Du gaaer fra mig - det er din Fader. - Sikkerheden og Bestemtheden i hendes Tone gjorde et sælsomt Indtryk paa mig, og dreven af en blind Nysgjerrighed forlod jeg Sibyllen. Udenfor saae jeg mig om - der var Ingen. Jeg gik strax til Gaarden - endnu Ingen. Men idet jeg drejer om og indad Porten, kommer den vanvittige Stodder lige imod mig." 24

Vangs forældre er Gale Bertel og spåkonen, og da han senere $\mathrm{i}$ historien atter dukker op med sin nyfundne familie, viser det sig, at han desværre ikke er faldet så langt fra stammen endda. Som følge af en pludselig indtrådt sindssyge, der især i ældre historier ikke så sjældent rammer plejebørn i den tidlige ungdom, præsenterer han sig selv og faren som berømte filosoffer og kaster sig derefter i en dramatisk scene ud i en længere udredning, der fører til skrig og besvimelser og endda dødsfald blandt hans tilstedeværende venner.

\section{Moderkærlighed}

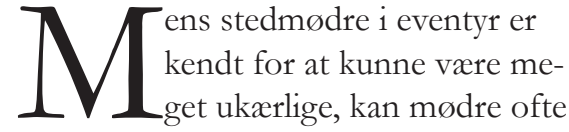
være stærkt knyttet til biologiske børn og meget utilbøjelige til at give dem fra sig.

Det gælder fx den stumme dronning, hvis svigermor stjæler hendes tre børn, som derefter bliver sat ud i et vandløb. Her bliver de fundet og optaget i tre forskellige nye familier. Men dronningen får mælet igen, og så snart hun får lejlighed til det, drager hun ud, opsø- 


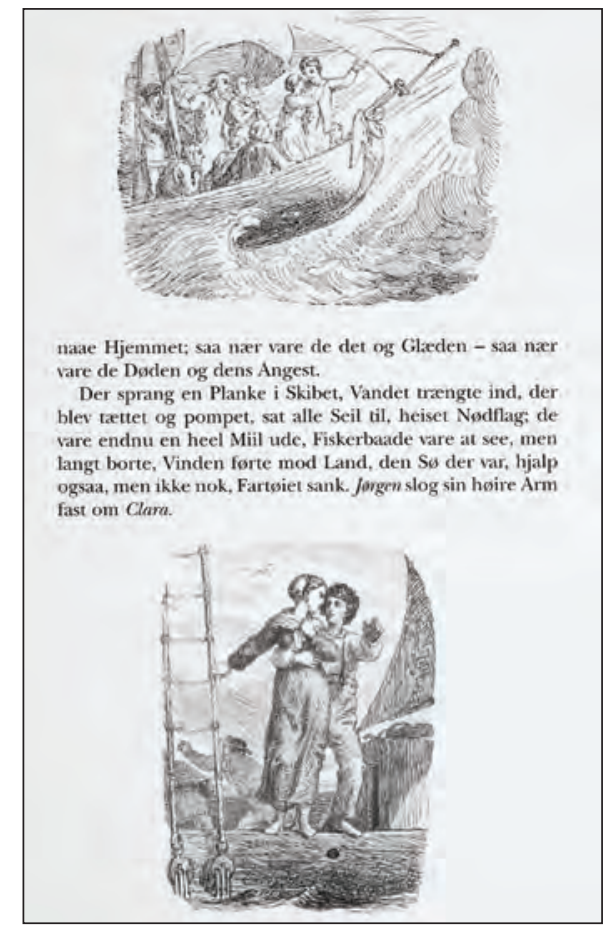

Jorgen og Clara på vej bjem fra Norge lige for skibet gàr ned. En Historie fra Klitterne of H.C. Andersen.

Tegning af Lorenz Frolich.

ger familierne og får ved hjælp af list og gåder sine børn med hjem igen. ${ }^{25}$

Også for mødre fra en langt senere epoke kan det være svært at måtte affinde sig med, at deres barn har fået ny familie.

En af dem, der har svært ved det, er Gurli, en ældre kvinde, som til daglig passer sit hjem og lever en meget almindelig og lidt kedsommelig tilværelse, men er ude af stand til at glemme Birgitte, den datter, hun i sin tid måtte bortadoptere. Eftersom hun kender navnene på det ægtepar, der fik hende, kan hun nemt finde dem i telefonbogen og tager til Bjerringbro for at undersøge sagen nærmere. Her opdager hun, at datteren er død for flere år siden, men efter at være kommet $\mathrm{i}$ besiddelse af et billede af hende får hun alligevel en form for ro i sindet:

"ansigtet var Gurlis. Kløften i hagen og opstoppernæsen. Selv den lille skønhedsplet under øjet var der. [...] Hun bar igen Birgitte (eller billedet af hende) under sit hjerte, og det var alt hvad hun havde ønsket."26

\section{Klaus Rifbjergs Falsk}

forår bliver den tyveårige Elisabeth fra Gentofte gravid, og forældrene får efter nogle alvorlige samtaler overbevist hende om, at adoption er den bedste løsning. Hun kommer herefter på "diskret ophold" hos nogle fjerne bekendte i Randers, får fødslen og adoptionen overstået og er ikke ked af at skilles fra sit barn, Tenna. Men syvogtredive år senere, da hun er blevet en rig og kendt forretningskvinde, bliver trangen til at få Tenna tilbage så stærk, at hun beslutter sig for at bryde ind i hendes nye liv og gennemtrumfer en genforening på trods af mange forhindringer i det lille fiskersamfund, hvor Tenna i mellemtiden havde fået opbygget en beskeden, men tilfredsstillende tilværelse. Følelserne for barnet ender alligevel med at få overtaget.

Dicte Svendsen, journalist og opdager, blev nødt til at bortadoptere sin søn, da hun var seksten. Mange år senere bliver hun inddraget $i$ en mordsag, hvor hendes søn er den mistænkte, og beslutter at opsøge ham. Han har haft et hårdt liv, efter hans adoptivforældre i sin tid skilte sig af med ham, han har været i fængsel, er blevet udstødt og bitter og afviser Dictes forsøg på 
at komme ham til undsætning. Men på trods af hans opførsel og drevet af følelser, hun selv ikke helt forstår, ender hun med at sætte hele sin tilværelse på spil for at redde ham; blodets bånd betyder noget for hende, og han er trods alt hendes kød og blod, selvom han er en utaknemmelig vaneforbryder. ${ }^{27} \mathrm{Al}-$ ligevel bliver det heller ikke her til nogen lykkelig genforening, da han ikke synes at være i stand til at gengælde hendes følelser.

Når de gamle temaer med den spændende historie, der kan byde på både dramatiske hændelser, sælsomme sammentræf og lykkelig genforening, bliver taget op i de senere år, er det ofte med en vis parodisk distance, som når det handler om Svend Åge Madsens Christian. Han er en pæn og sympatisk ung mand, hvis eneste problem med udseendet er et lille mærke på kinden. En dag, da han møder sine forældre i en tilfældig trappeopgang, fortæller de ham, at han ikke er deres biologiske barn, men at han blev stjålet fra andre som spæd, de ved bare ikke hvem. I forbindelse med den samtale, der nu følger, bliver der brug for et glas vand til at komme sig lidt. Så for at få et glas vand banker de på hos nogen et sted i nærheden, hvor der bor en hr. og fru Kurtsen. Fru Kurtsen ser mærket på kinden og genkender omgående sin søn, der blev stjålet som spæd. ${ }^{28}$

\section{Genfundne forældre}

$\mathrm{I}$ vore dage indledes rejsen mod genforeningen ofte med, at de unge tager initiativet og finder de officielle papirer i en skuffe eller får oplysninger fra de nye forældre, myndighederne eller fra andre, der tidligere har haft berøring med sagen.

Ligesom den biologiske mor i ældre eventyr og historier ofte viser sig at have været enten næsten ubemidlet eller meget fornem, men sjældent middelklasse - i modsætning til de nye forældre, der fx kan være fiskere eller gartnere, der uden at være velstående dog lige har det daglige udkomme - er der i nogle af de nyere historier en tilsvarende tendens til, at de biologiske mødre viser sig enten at høre til på samfundets absolutte skyggeside eller at høre hjemme blandt de privilegerede, velsituerede eller kendte - fx en beundret sangerinde og frihedskæmper, en kendt skuespillerinde eller en succesrig journalist, i modsætning til de mere almindelige gennemsnitsdanskere, som barnet kommer til at vokse op hos. ${ }^{29}$ Også mindelser om fremstillingen af den oprindelige mor som et mystisk, sagnagtigt, erotisk væsen, mænd møder og tiltrækkes af ude i naturen, som man så det i Christian Winthers fortælling om Lene, findes endnu. ${ }^{30}$

Generelt er der dog i mange historier kommet en mere realistisk, hverdagsagtig tone ind end tidligere, og det sker da ofte, at det miljø, som de unge finder frem til, ikke svarer helt til forventningerne. Det kan derudover være et problem, at de biologiske mødres oprindelige modvilje mod at skilles fra deres børn ikke er nogen garanti for, at deres følelser stadig er uændrede mange år senere. Alt $\mathrm{i}$ alt er det langtfra givet, at der bliver tale om nogen god oplevelse. 


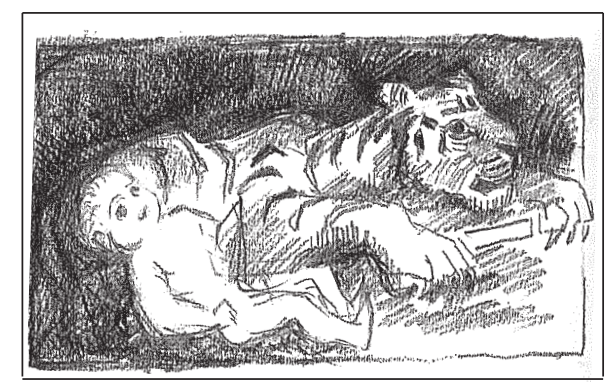

Fra Evald Tang Kristensens Eventyr fra Jylland, bistorien om 'prinsen og tigerbarnet, ved Vibeke Arndal; tegning af Erik Böttraun.

I en af de senere års spændingsromaner kan man fx læse om Karina, som finder tilbage til sine biologiske forældre i en lille svensk mineby. Her finder hun sin historie, men bliver også konfronteret med de overgreb og den umenneskelighed, der karakteriserede hendes første år, før hun kom til sine nye og langt tryggere rammer ved Hellerup og Strandvejen. ${ }^{31}$

Også andre adopterede bliver skuffede. For at få sin biologiske mor Valborg og sin tante at se uden at give sig til kende er en af dem kørt ind på en gård under påskud af at ville spørge om vej, men allerede tanten gør ham betænkelig. Han bliver i bilen, og mødet med hans mor bliver da også kort:

"Valborgs skikkelse toner frem foran vinduet. Han har allerede drejet nøglen og sat i gear, da hun bøjer sig ned, lægger underarmene på panelet og nysgerrigt ser ind. Lugten fra hendes krop overdøver dunsterne fra møddingen og de rådne roer.

Hun når ikke at se andet end et opslået landkort ved siden af førersædet. Bilen sætter fremad i et hug.

De står ved siden af hinanden og ser efter den. Valborg siger, at det er sådan en, de skal have, en himmelblå Opel Rekord." 32

$$
\text { Heller ikke for Kirsten }
$$

Thorups Karl er det nogen god løsning på problemerne at få kontakt med den biologiske familie. Hans mor er død, og det, som møder ham, er et følelseskoldt og voldeligt miljø. ${ }^{33}$

Skuffende kan det også virke, når adopteredes første møde med deres genfundne biologiske mor foregår på et cafeteria eller et plejehjem, og hun er en træt, grå kvinde, kroget og udslidt efter mange års hårdt arbejde, eller en senildement med gråhvide tjavser om indfaldne kinder og udtrådte hjemmesko. $^{34}$

Også når det første møde udvikler sig til et længerevarende forhold, er tonen i de nyere fortællinger gennemgående mere realistisk og hverdagsagtig end før. Det understreges som regel, at skuffelser specielt ved forholdets opstart er næsten uundgåelige, og at det næppe i længden kan blive det samme, som hvis der aldrig havde været nogen adskillelse. Efter den første genforening trækker begge parter sig lidt tilbage, og man indstiller sig på at sætte forventningerne lidt ned: "Efter det besøg blev jeg mere realistisk. Vi har skam kontakt endnu, bare ikke særlig hyppig. Vi følger lidt med i hinandens liv, så godt det nu kan lade sig gøre på afstand". ${ }^{35}$ Det er i de færreste tilfælde muligt at genetablere familieskabet uden større problemer, og man kan da højst håbe på at få etableret nogenlunde holdbare venskaber, hvis man da viser sig at have mere til fælles end det genetiske slægtskab. ${ }^{36}$ 
Men alligevel: selvom der er gået mange år, siden fru Gyllembourgs Nisida blev rakt ud gennem karetvinduet, er alt eventyrligt ikke rent forsvundet. Det findes stadig, også i nyere historier, - ikke mindst i føljetoner, hvor man fx kan læse om Inger: da hun er ganske lille, kommer hun og hendes familie ud for en voldsom eksplosion på en dansk jernbanestation, og i forvirringen bagefter kommer Inger bort fra de andre og ind i en togvogn og dukker først op igen noget senere, alene på en skovvej i det sydlige Sverige. Hun kan ikke fortælle noget om sin baggrund, og hendes familie bliver ikke fundet. Efter

\section{Noter}

1 Thomasine Gyllembourg: Samlede Skrifter, 7 (Reitzel, 1884), "Nisida", side 179.

2 Antti Aarne, Stith Thompson: The Types of the Folktale: A Classification and Bibliography (Helsinki, 1987), side 242: typenummer 707.

3 Christian Winther: Fortallinger paa Vers og Tresnit (Gyldendal, 1901), "Christen og Lene", side 336-338.

4 St. St. Blicher: Udvalgte V arker, 2 (Gyldendal, 1982), "Marie", side 115-116. - H. C. Andersen, H. C. Andersens samlede varker. Eventyr og Historier, 2 (Gyldendal, 2003), "En Historie fra Klitterne", side 308-310.

5 Thomasine Gyllembourg: "Nisida”, side 292.

6 Karen Blixen: Vinter-Eventyr (Gyldendal, 1972), "Det drømmende Barn", side 95.

7 Familie Journalen, 31/5 1999; Cai Renius: "Dobbeltspil", side 109.

8 Marianne Gade: Min kare Anna (Gyldendal, 1993), side 73.

9 Evald Tang Kristensens eventyr fra Jylland, ved Vibeke Arndal (Odense Universitetsforlag, 1995), "Drengen med de to sølvhår", side 242. at være vokset op hos nye forældre, som hun ikke har noget egentligt forhold til, bor hun først i København, men får derefter arbejde i provinsen, må flytte vestpå og havner i Bogense. Da hun på en regnvejrsdag tilfældigvis søger ly på et lokalt kunstgalleri, får hun pludselig øje på et maleri og opdager, at det forestiller hende selv som helt lille. Hun prøver nu at finde sine rødder, takket være maleriet lykkes det hende, og det bliver til en lykkelig genforening med hendes rige familie på herregården Egely lige syd for byen. ${ }^{37}$

Eventyret lever stadig og vil sikkert gøre det længe endnu.

10 Christian Winther: "Christen og Lene", side 336.

11 St. St. Blicher: "Marie", side 122.

12 H. C. Andersen, side 316.

13 Thomasine Gyllembourg, "Nisida", side 240.

14 St. St. Blicher: "Marie", side 116. - H. C. Andersen, side 331.

15 Karen Blixen: "Det drømmende Barn", side 115.

16 Vita Andersen: Anna Zö̈ (Samleren, 2006), side 113.

17 Nina Bolt: Ulvetimen (Tiderne Skifter, 2008), side 23-30.

18 Marianne Gade: Min kare Anna (Gyldendal, 1993), side 29-30. - Kirsten Thorup: Elskede ukendte (Gad, 1996), side 282-286.

19 Jf. anmeldelser i Politiken, 17/10 1989, 2. sektion, side 2; Det fri Aktuelt, 17/10 1989, side 21.

20 Kirsten Thorup: Elskede ukendte, side 285. - Jf. anmeldelser af Myung: Jyllands-Posten, 17/10 1989, Kunst og kultur, side 3. Det fri Aktuelt, 16/10 1989, side 33.

21 Kirsten Thorup: Elskede ukendte, side 260.

22 Grimms Eventyr, 2 (Gyldendal, 1995), oversat af Villy Sørensen, "De tre små fugle". 
23 St. St. Blicher: Udvalgte Varker, 3 (Gyldendal, 1983), "Fjorten Dage i Jylland", side 46.

24 Ibid., side 65.

25 Evald Tang Kristensens eventyr fra Jylland, "Prinsen og tigerbarnet".

26 Kirsten Thorup: Den yderste granse (Gyldendal, 1989), side 319.

27 Elsebeth Egholm: Vold og magt (Politikens Forlag, 2009), side 317.

28 Svend Åge Madsen: Tugt og utugt $i$ mellemtiden, 2 (Gyldendal, 2003), side 317-318.

29 Jf. fx Erik Amdrup: I skygge (Gyldendal, 1998); Nina Bolt: Ulvetimen (Tiderne Skifter, 2008).

30 Ib Michael: Prins (Gyldendal, 1997), side 303-304. Jf. også Bernhard Sev. Ingemann:
Samlede Eventyr og Fortallinger, 6 (Forlaget Danmark, 1913), "Den stumme Frøken", side 10.

31 Anders Westenholz: Fadrenes synder (Forum, 2003).

32 Anne Marie Løn: Prinsesserne (Gad, 1998), side 466.

33 Kirsten Thorup: Elskede ukendte, side 296299.

34 Jo Hermann: Idyl (Modtryk, 1999), "Adoptionen", side 54-55. - Ole Henrik Laub: Manden der så skeabnen i gjnene (Hovedland, 2000), side 201.

35 Marianne Gade, side 154.

36 Nina Bolt, side 290-291.

37 Familie Journalen, 1/2-22/3 1999; Cai Renius: "Pigen på maleriet". 